\title{
Creating legitimacy in water governance networks through complexity sensitive management
}

Jurian Edelenbos, Ingmar van Meerkerk and Erik Hans Klijn

\section{Book chapter, published}

\section{Reference:}

Edelenbos, J., I. van Meerkerk and E.H. Klijn (2013). Creating legitimacy in water governance networks through complexity sensitive management. In: Edelenbos, J., N. Bressers and P. Scholten (ed.). Connective Capacity in Water Governance. Pp. 267-289. Ashgate

A previous version of the manuscript was presented at:

Paper for the Annual NIG (Netherlands Institute of Government) Conference: Maastricht (2010, november 25 - november 26) 


\title{
Creating legitimacy in water governance networks through complexity sensitive management
}

\author{
Jurian Edelenbos, Ingmar van Meerkerk and Erik Hans Klijn
}

\section{Introduction}

Water projects are of complex nature, because these projects cross different governmental, jurisdictional, geographical and functional boundaries (Pahl-Wostl 2007; Edelenbos, 2010). Moreover, these projects are often developed and implemented in governance networks of interdependent actors, which employ dynamic interaction and negotiation processes with each other in order to find effective and legitimate solutions (Edelenbos et al, 2010b). The multi-faceted aspects of water projects stress the interconnected nature of these projects. Water touches upon the issues and interests of spatial planning, environment, nature, livability. The connection of different interests in package deals is important to realize legitimized outcome from water governance processes as already stressed in the first chapter of this book.

Network management is of major importance for the functioning and the performance of governance networks, including their democratic legitimacy (see for example Koppenjan and Klijn, 2004; Edelenbos \& Klijn, 2006; Klijn et al., 2010; Meier \& O'Toole, 2001, 2007). Network management is especially focused on organizing connections between different actors in different spheres, political, governmental and societal (Edelenbos et al, 2011). However, empirical insights in water governance network about the relationship between a connective style of network management and legitimacy is lacking.

In this chapter we will investigate this relationship by elaborating connective management style through the concept of complexity sensitive management, and its effect on different kinds of legitimacy. Data is gathered through survey research $(\mathrm{N}=272)$, which was conducted in 2010 among respondents involved in water projects in the Netherlands. These water projects are developed in complex governance networks, because they touch on the interests of a variety of public and non-public actors and their realization is dependent on these same actors (e.g. Koppenjan and Klijn, 2004; Sabatier et al, 2005; Lubell and Lippert, 2011; Edelenbos and Teisman, 2011). Throughout the chapter we will illustrate the survey results with qualitative case material. These cases were also part of the survey. This case material is collected by interviews and document analysis and is part of a study on water governance in The Netherlands (see Van Buuren et al, 2010).

This chapter is structured in the following way. In section 2 we elaborate the concept governance networks and its relationship with legitimacy. Subsequently, we discuss the relationship between complexity sensitive management - and legitimacy and formulate three research hypotheses in section 3. Section 4 is dedicated to our research methods and techniques, followed by a discussion of our findings in section 5 . We finish this chapter with section 6 in which we draw conclusions and further discuss the findings. 


\section{Water governance networks and legitimacy}

Governance networks and the issue of legitimacy

Within contemporary public administration theory it is recognized that many decisionmaking processes take place within interdependent sets of actors (e.g. Marsh and Rhodes, 1992; Rhodes, 1997; Kickert et al., 1997; Pierre and Peters, 2000; Sorensen and Torfing, 2007). This also applies for the sector of water (resource) management (Pahl-Wostl, 2007). We therefore depart from a view on networks, which approaches networks as loosely coupled interrelationships between governmental, societal and private actors around policy problems.

Although the literature on governance networks is not well-developed on the topic of legitimacy, it does suggest that governance networks represents a threat to representative democracy, but is not necessarily a threat to democracy as such (Sørensen and Torfing, 2007b: 233). Governance processes in governance networks offer "...new ways of connecting public policy-making to citizens and stakeholders, overcoming the constraints and limitations of representative democracy and party politics" (Klijn \& Sklecher, 2007: 588). There is however very little empirical work on the democratic nature of governance networks although theoretical work on this is growing (see Sorensen and Torfing, 2007).

Governance networks and different sources and forms of legitimacy

Regarding defining the concept 'legitimacy' it is important to make a distinction between two levels: (1) the legitimacy of governance networks as a system, and (2) the legitimacy of governance practices unfolding in governance networks. Systemic legitimacy is about the acceptance of a governance regime or political institutions (e.g. Held, 2006) and is often the focus of political science oriented research. Governance practice legitimacy is focused on the legitimacy of concrete policy and decision-making processes. In this chapter we focus on the latter definition. Building on Scharpf (1999), we distinguish three different types of legitimacy: (1) output, (2) throughput, and (3) procedural legitimacy. Instead of input legitimacy we focus on procedural legitimacy. Input legitimacy is about mechanisms or procedures to link preferences of citizens to political decision-making and accountability structures (Scharpf, 1999; Van Kersbergen and Van Waarden, 2004). However, because governance networks are a-constitutional (Mathur and Skelcher, 2007: 229), it is less easily to locate loci of power. We therefore focus on following formal procedures as an instrument to gain accountability. In the proceeding paragraphs, we further elaborate these three types of legitimacy.

In literature, output legitimacy is built up out of two dimensions. The first dimension is about the problem solving capacity of policy outputs generated by governance processes. Political choices and public policies are legitimate if they will generally represent effective solutions to common problems of the governed (Scharpf, 1999). The second dimension of output legitimacy is about the acceptance of policy outputs by citizens and stakeholders (e.g. Edelenbos et al., 2010). Some scholars argue that legitimacy comes from pragmatic consideration when stakeholders (citizens, NGOs, etc.) believe that decision-making outcomes are relevant and in their own interests (Held, 2006; Kooiman, 1993; 2000). 
Throughput legitimacy is about the democratic quality of the process (Dryzek, 2000). Openness, accessibility and transparency are often-mentioned aspects of this kind of legitimacy (Macpherson, 1979; Berry et al, 1993; Scharpf, 1999, Hirst, 2000; Young, 2000; Held, 2006). By involving more actors (and certainly citizens), decision-making acquires a less closed character, leading to more transparency, deliberative quality, and mutual understanding (Dryzek, 2000).

Procedural legitimacy means that democratic legitimacy is gained by following formal governmental procedures and rule of law (see Luhmann, 1969; Esmark, 2007). Legitimacy is achieved if decisions are made according to procedures that include some forms of accountability such as the rule of law (Van Kersbergen and Van Waarden, 2004: 156). It "...implies that some actors have the right to hold other actors to a set of standards, to judge whether they have fulfilled their responsibilities in light of these standards and to impose sanctions if they determine that these responsibilities have not been met" (Grant and Keohane, 2005: 29).

How the different forms of legitimacy are unfolding in practice is highly dependent on the specific context. O'Toole (1997: 458) argues that network management “...provides both complications and opportunities to facilitate parts of the democratic ideal". In the next section we elaborate this thought, focusing on the role of network management.

\section{Network management and its influence on legitimacy}

Network management is in essence an inter-organizational activity (Hanf and Scharpf 1978; Gage and Mandell 1990; Kickert et al, 1997). Network management is about connecting people and is focused on enabling interactions and relationship building in order to develop and explore content and attempt to come to an agreement on sharing resources and joint action (Rogers and Whetten, 1982; Scharpf, 1978). Research on network management shows that network management activities that are focused on developing relations between actors from different organizations through for example selective (de)activation and boundary spanning activities have an (significant) impact on achieving good (process and content) outcomes (Klijn et al, 2010). The management of complex water issues is about making meaningful connections between a wide variety of actors from different layers, domains and sectors (Edelenbos, 2010). Thus, connecting is an important network management strategy in water (resource) management.

Management in governance networks often clashes with institutions of representative democracy (Edelenbos, 2005). Representative democracy provides the democratic foundations of hierarchical-instrumental policy making (Wagenaar, 2007: 41). This way of policy-making often conflicts with the horizontal processes in governance networks (e.g. Kickert et al., 1997; Klijn and Skelcher, 2007; Wagenaar, 2007; Teisman et al., 2009). Managers operating in governance networks have to deal with this tension; they have to deal with institutions which are based on traditional foundations of representative democracy on the one hand and the fragmented and complex reality of governance networks with all kind of actors (citizens, NGOs, companies, etc.) on the other hand (Klijn and Skelcher, 2007). This tense full context 
requires an adaptive or a complexity sensitive network management style (Edelenbos and Klijn, 2009; Teisman et al, 2009).

A complexity oriented or complexity sensitive management style as we call it in this chapter is considered to be more suited to solving complex issues within governance networks (c.f. Teisman et al, 2009). This management style is based on approaching complex phenomena in a holistic manner (Uhl-Bien et al, 2007; Edelenbos et al., 2009; Jackson, 2000; Rosenhead, 1998; Senge, 1990). It is therefore more oriented at the interactions and the interdependencies between parts of issues and networks. It means that managers do not draw strict lines between different parts of complex issues and policy processes, but are rather oriented towards making meaningful connections and embeddedness (Edelenbos 2010). A complexity sensitive management style is oriented at creating the context in which effective and legitimate governance processes could unfold.

In the remaining of this section we will formulate three hypotheses regarding the relationship between a complexity sensitive management style and the three different forms of legitimacy distinguished in this chapter.

In line with the literature on complexity management one can argue that a complexity sensitive management style will enhance certain forms of legitimacy and will undermine other forms of legitimacy. Firstly, the focus on stakeholder diversity and stakeholder interaction contributes to "...the flow of experiential knowledge through the system so that they enable actors in the system to produce, appreciate, and select productive intervention strategies and arrive at the coordination of problem solving and decision making" (Wagenaar, 2007: 18). Hence, including different stakeholders and organizations could result in solutions which cover the diversity of functions and interests, touched by the complex issue at stake, - leading to relevant and supported outcomes (Teisman et al, 2009; Edelenbos, 2010). Giving room for other interests could stimulate governance processes in which stakeholders are thinking along with policy initiators and solving the policy issue at stake, rather than organizing resistance against policy initiators. Furthermore, it enhances the chance of the emergence of unforeseen combinations of viewpoints, and therefore innovative solutions (Uhl-Bien et al., 2007). In all we expect higher output legitimacy through a complexity sensitive management style in governance networks:

\section{H1: A complexity sensitive management style within governance networks dealing with complex water projects will lead to higher output legitimacy.}

Moreover, complexity sensitive network management is focused on the involvement of a broad range of stakeholders. Instead of reducing the administrative complexity by focusing on a few parties who are in charge, the manager involves different stakeholders with different interests (Hazy, 2008; Edelenbos et al, 2009). The management style is focuses on inclusion of stakeholders, and transparency of the process. This means that a complexity sensitive management style should provide more opportunities for interaction, deliberation and debate (Dryzek, 2000; Edelenbos et al., 2010b). Therefore, we expect a positive relationship between complexity sensitive management style and throughput legitimacy: 
$\mathrm{H} 2$ : A complexity sensitive management style within governance networks dealing with complex water projects will lead to higher throughput legitimacy.

A complexity sensitive management style takes the dynamics around a project into account, and provides opportunities for stakeholder interactions and influence on the course of action (Edelenbos et al., 2009). We expect that the manager is mainly focused on the environment of the project; adapting initial preferences to emerging demands of stakeholders in the environment of the project. This outward orientation comes at the expense of the inward orientation, i.e. the way shareholders (the core actors in the governance network) approach problems and solutions and normal procedures that are being followed, which are focused on efficiency and control (Schreiber and Carley, 2008: 294). Hence, we expect that the needed flexibility for a complexity sensitive management style contrast with the institutionalized way of working within traditional public bureaucracies. This leads to our third hypothesis:

H3: A complexity sensitive management style within governance networks dealing with complex water projects will lead to lower procedural legitimacy.

\section{Research method, sample and measurement}

In this section the methodological aspect of the conducted research is discussed. First we discuss research methods and sample. Subsequently measurement issues are addressed.

\section{Research method: survey approach}

To examine complex water issues in governance networks we conducted a survey among participants in water projects with a spatial land use character in The Netherlands. In The Netherlands, spatial planning projects and water projects are often related, because of the strong presence of water and water related issues. These 'water related land use' projects have often a complex nature, because a variety of spatial functions (e.g. housing, infrastructure, agriculture, nature development and water retention) are included and different domains (policy sectors), governance levels and private/societal actors are involved (e.g. Van Buuren et al., 2010).

We collected data from a web-based survey held in 2010 (April-May). We were able to acquire 874 e-mail addresses of people from our target group, by utilizing the mailing list of 'Living with Water'. This is a national research program directed at developing and sharing knowledge about management of complex water projects which are being developed in interaction with spatial/environmental functions in the Netherlands. ${ }^{1}$ Different types of organizations collaborate in this program, including municipalities, water boards, environmental interest groups, building contractors and project management organizations. Furthermore, individual participants, such as residents

\footnotetext{
${ }^{1}$ Living with Water has established itself as a fairly important network organization with many members. If we examine the projects that are mentioned by the respondents, then almost all of the well-known spatial water projects in the Netherlands are represented (and of course a number that are less well known), which gives confidence that this is a fairly reasonable sample of the available spatial water projects in the Netherlands.
} 
living in project areas are also part of the mailing list. The mailing list is, among other things, used for providing information on certain water projects and policies. Considering the variety of actors on this mailing list, we argue that our respondents represent different organizational backgrounds actors have in networks around complex water projects. ${ }^{2}$ The respondents also represent different levels of participation: they include managers, closely involved participants, and bystanders (see below).

\section{Population, sample and unit of analysis}

Table 1 describes the population and sample used for the survey, and the number of respondents who have returned the questionnaire. A total of 272 questionnaires $(31.1 \%)$ were returned. After conducting a missing value analysis, 200 respondents were included in the analysis. The removed questionnaires ( 72 cases) were not completed.

We asked the respondents at the start of the questionnaire to name the project of which they have been mostly involved and to answer the questions regarding this project. The 200 respondents were involved in 166 different water projects. These water projects are geographically dispersed over the Netherlands. Because there are several respondents who are involved in the same water project and thus the same governance network, we randomly selected one respondent for each project. In this way we made sure that the data from the different respondents are independent.

Table 1 Population and sample

\begin{tabular}{|l|l|}
\hline $\begin{array}{l}\text { Number of people on Living with Water List (after } \\
\text { removing researchers, communication and } \\
\text { marketing bureaus, etc.) }\end{array}$ & 874 \\
\hline Returned questionnaires & 272 \\
\hline $\begin{array}{l}\text { Sample after removing questionnaires with too } \\
\text { many missing data }\end{array}$ & 200 \\
\hline Analyzed questionnaires (1 respondent per project) & 166 \\
\hline
\end{tabular}

\section{Characteristics of our respondents}

Because the different respondents have different backgrounds, considering the different types of organizations on the mailing list, we made a general distinction in the role of the respondent in the project. The majority of our respondents $(75 \%)$ are the most active actors in the project. This group consists of managers (36\% of total sample) and respondents who are actively participating in the project (39\% of total sample). The other quarter of our respondents (25\%) consists of people who are less actively involved in the project (respondents who think along in certain parts of the project or bystanders). Because these different positions could influence the perceptions of the way in which the manager operate and how the legitimacy of the projects is judged, we included the position of the respondent as a control variable in our regression analyses (see below). Furthermore, we asked for the experience of our respondents in complex projects. On average, the respondents of our survey have been involved in complex projects for twelve years. This shows that the respondents are quite experienced in dealing with governance networks. However, the standard deviation is high $(8,81)$, which means that large

\footnotetext{
${ }^{2}$ The addresses of researches, marketing and communication bureaus were deleted from the list. We only wanted to survey stakeholders within the governance networks around the complex spatial-water projects (including the initiating actors and residents).
} 
differences exist. Therefore, we also included experience as a control variable (see below).

Characteristics of the water projects and the governance networks

To measure the complexity of the projects and of the networks we asked several questions concerning the project and network characteristics (see Agranoff and McGuire, 2001; Kickert et al., 1997; Klijn et al., 2010a; Koppenjan \& Klijn, 2004; Sørensen \& Torfing, 2007). In table 2 an overview of the outcomes is provided. 92,2\% of the respondents respond that 'their' water project is related to other projects. On average about 3 planning activities or spatial functions are combined in the project. However, the standard deviation of 1,5 is quite high, indicating that in some projects considerably more planning activities are combined than in others. In 50,9\% of the cases 3 or more spatial functions (such as nature development, housing, water retention, recreation etc.) were involved and in $25,5 \%$ of the cases 4 or more spatial functions were involved. $90,4 \%$ of the respondents participate in a water project with more than 5 actors involved; in 53\% of the cases more than 10 actors are involved and in $27,7 \%$ of the cases even 20 actors or more are participating. $76,7 \%$ of the respondents state that they are strongly dependent on other actors within the network. These results indicate that the projects in which the respondents participated are developed in governance networks.

\begin{tabular}{|c|c|c|}
\hline Number of different activities & $\begin{array}{l}\text { Mean }=2,73 \\
\text { (sd: } 1,5)\end{array}$ & $\begin{array}{l}\text { Includes water storage, houses, } \\
\text { business terrain, environmental } \\
\text { development, commercial } \\
\text { development, infrastructure (rai } \\
\text { and public highways) }\end{array}$ \\
\hline \multicolumn{3}{|l|}{ Project includes: } \\
\hline Water storage & $95,8 \%$ & \\
\hline Construction of houses & $47,2 \%$ & \\
\hline Nature development & $82,2 \%$ & \\
\hline Experienced dependency & $\begin{array}{l}M=3,90 \\
\text { (sd: } 0,90)\end{array}$ & 5 point Likert scale \\
\hline Level of conflict & $\begin{array}{l}M=2,89 \\
\text { (sd: } 1,09)\end{array}$ & 5 point Likert scale \\
\hline Unexpected events & $\begin{array}{l}\mathrm{M}=3,33 \\
\text { (sd: } 0,94 \text { ) }\end{array}$ & 5 point Likert scale \\
\hline
\end{tabular}

\section{Measurement}

Core variables

In this chapter we look at four core variables: (1) output legitimacy, (2) throughput legitimacy, (3) procedural legitimacy, and (4) complexity sensitive management style. All the answers on the different items concerning these core variables were given on a fivepoint Likert scale ranging from totally disagree to totally agree or ranging from certainly 
not to certainly yes. Because we make use of a survey we actually only could make use of the perceived outcomes of the different involved participant of the projects.

Measuring our independent variable: complexity sensitive management (CSM)

The managers in our survey are public managers working in or for governmental organizations. In our conceptualization complexity sensitive management means that the manager is sensitive for the interdependencies and interactions between different parts of complex issues (Choi et al., 2001; Teisman, 2005; Edelenbos \& Teisman, 2008). We measured this variable by four different items, (see appendix I for the concrete survey questions) (Koppenjan and Klijn 2004; Edelenbos and Klijn 2006; Teisman, 2005):

- A complexity sensitive manager is aimed at connecting different spatial functions in the development of the project;

- The manager tries to adapt the project to the demands and wishes of the stakeholders;

- The manager tries to keep the project in line with the expectations of the involved stakeholders. It therefore creates enough time for representatives to discuss the developments with their grass-roots;

- A complexity sensitive manager tries to connect the different interests which are present in governance networks.

The Cronbach's alpha of the four items was 0.71 .

Measuring our dependent variables: legitimacy

Output legitimacy

As described in section 2, we distinguish two dimensions of output legitimacy: the problem solving capacity of the policy outputs and the acceptance of these outputs by stakeholders. Building on prior survey research (Edelenbos et al, 2010, Klijn et al 2010a) we have used the following four items to measure output legitimacy. These items formed a reliable scale, with a Cronbach's alpha of .72. The concrete questions can be found in appendix I. The two items concerning the problem-solving capacity:

- The extent to which the solutions really address the problem, the responsiveness (see Innes and Boohler 2003; Scharpf, 1999);

- The robustness of the results, that is, the future robustness (time frame) of the results (see Koppenjan and Klijn 2004);

The two items concerning the acceptance of the policy outputs and decisions (Edelenbos et al., 2010):

- The support for the results of the governance process;

- The support for the substantiation of the decisions.

\section{Throughput legitimacy}

As we described above throughput legitimacy is about the quality of the process. We used six items (see appendix I) to measure three different aspects of the democratic quality of the process (Bekkers and Edwards, 2007; Dryzek, 2000; Edelenbos and Klijn, 2006; Edelenbos et al., 2010; Klijn, 2009; Scharpf, 1999): 
- Voice. This refers to the depth (the intensity and the influence of stakeholders) and width (how many stakeholders) of participation;

- Due deliberation. This aspect focuses on the quality of the deliberation process: the extent to which there were real opportunities for debate and the quality of the argumentation process;

- Transparency. This aspect focuses on the availability and accessibility of information. In this way participants are better able to make well-informed judgments and arguments.

The six items of throughput legitimacy resulted in a scale with a Cronbach's alpha of .80 .

\section{Procedural legitimacy}

Procedural legitimacy is about gaining legitimacy from institutionalized governmental procedures and rule following behavior (Koppenjan and Klijn, 2004; Edelenbos, 2005). In our questionnaire we distinguished therefore two items measuring to what extent the governance process has been structured by following formal procedures (see appendix I):

- Determination of the governance process by a priori determined procedures and rules; and

- Emphasis on compliance to formal rules and procedures.

These items formed a scale with a Cronbach's alpha of .75.

\section{Control variables}

Of course, legitimacy could be influenced by a lot of other variables. To test the influence of specific respondent and project characteristics on the outcomes the following control variables are involved in the analysis.

\section{Project phase}

The phase of the project can also influence the perception of management style and/or level and form of legitimacy. For instance, almost by definition there will be fewer outcomes in the first phases of a spatial project, and therefore influence output legitimacy. We distinguished seven different phases in the activities around the water/spatial projects (see the appendix for the items). In most of the cases $(63,0 \%)$ the project plan is developed and realized by elected representatives. In 31,5\% of the cases construction activities are already taken place. To include this variable in the analysis we added the different finished activities per respondent.

Characteristics of the environment of the network

The characteristics of the environment of the network could probably influence management style and legitimacy. We asked respondents to indicate the environment of the governance network. They could indicate on a five point Likert scale the a. stability of the environment, b. the relationship with other projects, and c. the level of differences of opinion about the project. $69,8 \%$ of the respondents indicates that the governance network of which they are part operates in a changing (political, social, and/or economical) environment. $92,1 \%$ of the respondents responds that the water project is 
related with other projects. $33,8 \%$ of the respondents indicates that there are many differences in opinions concerning the direction of the project.

\section{Characteristics of the governance network}

The characteristics of the governance network could probably influence management style and the level and form of legitimacy in the projects. We asked respondents to indicate the nature of the governance network (see above). ${ }^{3}$

\section{Characteristics respondent}

Because both managers and other participants in the project are surveyed it is important to check if managers perceive their style and the outcomes of the project differently compared to other participants in the project. For the analysis, we made a distinction between three kinds of involvement: (a) respondents who followed the project from a distance or who were thinking along with the project $(25 \%)$, (b) respondents who actively participated in the project $(39 \%)$, (c) managers of the project $(36 \%)$. Furthermore, we asked respondents to indicate their experience with complex projects. This could possibly influence the perception of the management style and/or legitimacy. For example, participants who have more experience possibly know the difficulties of managing such projects and have a kind of reference for judging the managers' style. The mean experience of our respondents was 12.09 years, with a standard deviation of 8.81.

\section{Findings}

Table 3 shows the correlations among all the variables included in the analysis. The table shows that complexity sensitive management is strongly correlated with output and throughput legitimacy: a positive correlation of 0.38 and 0.39 respectively. These correlations are in line with our hypotheses. However, there is no correlation between management and procedural legitimacy, which is not in line with hypothesis 3 . Furthermore, the correlation table shows that output and throughput legitimacy are highly correlated (0.48). This is not surprising: when respondents are satisfied with the process, then they are also often satisfied with the output or vice versa. The relationship between output and throughput legitimacy on the one hand and procedural legitimacy is negatively correlated (-0.21 and -0.22 respectively). Although there is no correlation between management and procedural legitimacy, these outcomes are in line with our theoretical argumentation that the creation of output or throughput legitimacy could hamper

\footnotetext{
${ }^{3}$ We firstly asked the respondents to indicate the number of actors involved in the governance network. Respondents could indicate one of the following categories: a. less than 4 actors, b. 5 till 9 actors, c. 10 till 14 actors, d. 15 till 19 actors, e. 20 actors or more. $92,1 \%$ of the respondents participate in a water project with more than 5 actors involved; in 58,3\% of the cases more than 10 actors are involved and in $30,1 \%$ of the cases even 20 actors or more are participating. Secondly, respondents were asked to score on a five point Likert scale the level of interdependencies with other actors in the network and the occurrence of unexpected events in the governance network. $79,8 \%$ of the respondents state that they are strongly dependent on other parties within the network. 48,4\% of the respondents state that there are often unexpected developments and turnings in the network (against 19,2\% of the respondents which state that this is not the case).
} 
procedural legitimacy or vice versa. Apparently, these different forms of legitimacy could contradict each other.

Furthermore, the level of conflict in the networks (differences of opinion) is negatively correlated with output legitimacy (-0.40). This is not surprising. In networks with a high level of conflict stakeholders are likely to be more sceptical regarding the acceptance and valuation of policy outputs. Interestingly, the level of the respondent's involvement did not really matter regarding the perception of the different core variables. Only managers are a bit more positive regarding their sensitivity towards complexity in the governance networks we examined.

In the remaining of this section we subsequently focus on the three research hypotheses by using OLS regression analyses. First we pay attention to our first hypothesis: a complexity sensitive management style within governance networks dealing with complex water projects will lead to higher output legitimacy. We used OLS regression analysis with output legitimacy as dependent variable. Table 4 shows the results of this analysis. 
Table 3: Descriptive statistics and correlations between variables in analysis

\begin{tabular}{|c|c|c|c|c|c|c|c|c|c|c|c|c|c|}
\hline & CSM & OuLe & ThLe & PrLe & $\mathrm{PF}$ & RoP & SN & In & $\mathrm{DO}$ & MA & $\mathrm{Pa}$ & $\mathrm{Ot}$ & YE \\
\hline CSM & 1 & & & & & & & & & & & & \\
\hline OuLe &, $378 * *$ & 1 & & & & & & & & & & & \\
\hline ThLe &, $393 * *$ &, $475 * *$ & 1 & & & & & & & & & & \\
\hline PrLe &,- 131 &,$- 212 * *$ &,$- 218 * *$ & 1 & & & & & & & & & \\
\hline $\mathrm{PF}$ & ,064 & ,226** & ,098 &, $232 * *$ & 1 & & & & & & & & \\
\hline RoP & ,152 &, 007 & ,079 &,- 106 & ,003 & 1 & & & & & & & \\
\hline SN &, $194 *$ & ,033 &, $211 * *$ &,- 063 &,- 058 & ,117 & 1 & & & & & & \\
\hline In &, 129 & ,135 &, $172 *$ &,- 097 &,- 045 & ,134 & ,046 & 1 & & & & & \\
\hline DO &,$- 167 *$ &,$- 403 * *$ &,- 143 &,- 006 &,- 129 &, 083 &, 001 &, $186 *$ & 1 & & & & \\
\hline $\mathrm{Ma}$ &, $175^{*}$ & , 156 & ,067 &,- 113 &, $185^{*}$ & ,138 & , 120 & ,026 &,- 100 & 1 & & & \\
\hline $\mathrm{Pa}$ &,- 055 &,- 040 &, 070 &, 027 &,$- 196 *$ &,- 002 &,- 099 &, 044 &, 150 &,$- 596 * *$ & 1 & & \\
\hline Ot &,- 133 &,- 130 &,- 152 & ,096 &, 014 &,$- 151 *$ &,- 023 &,- 076 &,- 057 &,$- 438 * *$ &,$- 461 * *$ & 1 & \\
\hline YE &,- 050 &, 094 &, 027 & ,086 &, 073 &,- 059 &,- 029 &, 110 & ,013 &,- 068 &, 103 &,- 039 & 1 \\
\hline
\end{tabular}

Depending on the number of missing values, $N$ is between 153 and 166

${ }^{* *} p<0,01 ;{ }^{*} p<0,05$

\section{Legend}

CSM: Complexity Sensitive Management

OuLe: Output Legitimacy

ThLe: Throughput Legitimacy

PrLe: Procedural Legitimacy

Tr: Trust

PF: Project Phase

RoP: Relationship with other

Projects

SN: Size Network

In: Interdependency between

network parties
DO: Differences of opinion

between parties

Ma: Position respondent:

manager

Pa: Position respondent:

participant

Ot: Position respondent: Other

YE: Years of experience

respondent with complex

projects 
Output legitimacy

Table 4 Results of Ordinary Least Squares Regression Analysis with output legitimacy as dependent variable $(\mathbf{N}=\mathbf{1 5 3})$

\begin{tabular}{|c|c|c|c|}
\hline Model & & & \\
\hline & B & Beta & Sig \\
\hline (Constant) & 3,087 & & $.000^{* *}$ \\
\hline Complex sensitive management & ,224 & ,285 &, $000^{* *}$ \\
\hline Characteristics project & & & \\
\hline - $\quad$ Project phase &, 046 & ,147 &, $043^{*}$ \\
\hline - Relationship with other projects &,- 026 &,- 037 & ,609 \\
\hline Characteristics network & & & \\
\hline - Size &,- 007 &,- 018 & ,805 \\
\hline - Interdependencies & ,089 &, 150 &, $041^{*}$ \\
\hline - Differences of opinion &,- 179 &,- 366 &, $000^{* *}$ \\
\hline Characteristics respondent & & & \\
\hline $\begin{array}{l}\text { Position } \\
\quad(\text { manager }=\text { reference category })\end{array}$ & & & \\
\hline participant &,- 008 &,- 007 & ,931 \\
\hline other &,- 134 &,- 110 & , 176 \\
\hline - Years of experience with complex projects &, 004 &, 070 & ,327 \\
\hline
\end{tabular}

$* \mathrm{p}<0.05 * * \mathrm{p}<0.01$

Table 4 shows that there is a significant, positive relationship between complexity sensitive management style and output legitimacy. We also see that there is negative significant relationship between level of conflict (differences of opinion, a characteristic of the specific governance network) and output legitimacy. In sum, our first hypothesis can be confirmed; complexity sensitive management leads to higher output legitimacy.

To give this finding on output legitimacy more qualitative flavor we shortly discuss one of the projects, case Noordwaard, in the box below. 
Box 1: case illustration on output legitimacy

Case illustration from the survey: the case Noordwaard

The Noordwaard is a polder of nearby 2,500 hectares alongside the river New Merwede in The Netherlands. It has a mainly agricultural and residential function and consists of 75 farm and non-farm households. The Noordpolder area is located between the river New Merwede and the natural reserve area Biesbosch. By making the Noordpolder available for retention during high river discharges a water level fall could be realized of about 60 centimeters in the Merwede and 30 centimeters near Gorinchem, a city threatened during river flooding.

Two managers from the national department of Infrastructure and Environment were appointed to organize and implement the project. They implemented a very open and stakeholder oriented process. The managers implemented a very complexity sensitive management style, in which all kind of stakeholders (NGOs, citizens, farmers, etc.) got the opportunity to get involved in the process and to provide information, thoughts, interests and wishes. Through interactive design sessions, workshops and discussion meetings a kind of alternatives were explored. In these sessions of civil servants, external experts and stakeholders the "Noordwaard option" was born. In several interactive sessions the 'run-through' alternative emerged, which makes the inner part of the area available for temporary water retention when the river Merwede needs more space. The outer parts (left and right) are protected against flooding and available for land use (residential and agricultural functions). At the same time, the stakeholders managed to enforce a couple of conditions for developing the Noordwaard option:

- inhabitants have the opportunity to stay;

- inhabitants are given clarity within two years. The Noordwaard project should become a frontrunner project (see above);

- $\quad$ people who have to move out will get reasonable compensation;

- inhabitants and landowners (mostly farmers) are actively involved in planning.

Especially the first point was a victory for farmers and residents. In case of people moving out, the national government had to provide new locations in the same area.

In all, the Noordwaard option was considered an effective solution in coping with flooding. This option was the result of an extensive interactive, stakeholder oriented process. The output was broadly accepted by the stakeholders. This case illustrates how a complexity sensitive style of management resulted in high output legitimacy.

\section{Throughput legitimacy}

Now we turn to our second research hypothesis: a complexity sensitive management style within governance networks dealing with complex water projects will lead to higher throughput legitimacy. We used a OLS regression analysis with throughput legitimacy as dependent variable. Table 5 shows the results of this analysis.

Table 5 shows that there is a significant positive relationship between complexity sensitive management style and throughput legitimacy. Hence, our second hypothesis can be confirmed. Furthermore, we see a positive significant relationship between size of network (as a governance network characteristic) and throughput legitimacy. We can conclude that process legitimacy gets higher when the network size, i.e. the actor relationships, increases. Interaction among more actors in the network seems beneficial for realizing throughput legitimacy. 
Table 5 Results of Ordinary Least Squares Regression Analysis with throughput legitimacy as dependent variable $(\mathrm{N}=\mathbf{1 5 4})$

\begin{tabular}{|c|c|c|c|}
\hline \multicolumn{4}{|l|}{ Model } \\
\hline & $\mathrm{B}$ & Beta & Sig \\
\hline (Constant) & 2,262 & &, $000^{* \star}$ \\
\hline Complex sensitive management & ,262 & 319 &, $000^{* *}$ \\
\hline \multicolumn{4}{|l|}{ Characteristics project } \\
\hline - $\quad$ Project phase & 028 & 085 & ,272 \\
\hline - Relationship with other projects &,- 002 &,- 003 & ,966 \\
\hline \multicolumn{4}{|l|}{ Characteristics network } \\
\hline - $\quad$ Size &, 063 &, 157 &, $043^{*}$ \\
\hline - Interdependencies & 082 & ,133 & 092 \\
\hline - Differences of opinion &,- 063 &,- 122 &, 123 \\
\hline \multicolumn{4}{|l|}{ Characteristics respondent } \\
\hline \multicolumn{4}{|l|}{$\begin{array}{ll} & \text { Position } \\
(\text { manager }=\text { reference category })\end{array}$} \\
\hline participant &, 120 & , 105 & ,235 \\
\hline other &,- 070 &,- 055 &, 524 \\
\hline \multirow[t]{2}{*}{ - Years of experience with complex projects } & ,001 & ,012 & ,875 \\
\hline & \multicolumn{3}{|l|}{$\begin{array}{l}\mathrm{R}^{2}=, 223 \\
\mathrm{R}^{2}{ }_{\text {adj }}=, 173\end{array}$} \\
\hline
\end{tabular}

$* \mathrm{p}<0.05 * * \mathrm{p}<0.01$

Box 2: case illustration on throughput legitimacy

Case illustration: Bypass Kampen IJsseldelta

The project IJsseldelta-South is focused on the area between the city Kampen, the river IJssel en the Dronterlake in The Netherlands. The goal of this project is the improvement of water safety, the living and working conditions and the infrastructure. Moreover, the project wants to improve the agricultural sector in the area. To keep the area safe from the water from the sea or river - the IJssel - the project IJsseldeltaSouth anticipates on the realization of a bypass river from the IJssel to the Dronterlake. This bypass makes it possible to retain and recover the quality of the national landscape in the IJssel area.

In the first round of the process started in 2000 the orientation was mainly on the inclusion of governmental actors (like water board, municipality, central agency Rijkswaterstaat and the province of Overijssel). In a relative closed arena five alternatives for the bypass were developed. This resulted in fierce resistance from a local association, which was against this location because it would geographically divide two communities in the area. This resistance became apparent in an informative meeting with stakeholders. In response, the delegate of the province of Overijssel gave the association the opportunity to develop their own alternative, and promised support from his administration in developing this alternative. As result a 6th scenario was born. This scenario consisted of a blue bypass on a different location, nearby the city of Kampen in a green area. The province of Overijssel took the role of process manager. The province implemented organizational arrangements, like the steering board (for deputies from the governments), the 
project organization (civil servants from the governments) and the sounding board (for stakeholders). Stakeholders were informed periodically about the project and they were given opportunity to give input. This process approach led to a change in the way stakeholder perceived and valued the process. The change from an exclusive, inward oriented process approach towards an inclusive, outward oriented process approach was highly appreciated by the stakeholders.

In all, a complexity oriented management style emerged in which transparency and voice were important conditions. This led to high valuation of process legitimacy of the project.

\section{Procedural legitimacy}

Finally, we take closer look at hypothesis 3: a complexity sensitive management style within governance networks dealing with complex water projects will lead to lower procedural legitimacy. Table 6 shows the results of OLS regression analysis with procedural legitimacy as dependent variable.

Table 6 Results of Ordinary Least Squares Regression Analysis with procedural legitimacy as dependent variable $(\mathrm{N}=\mathbf{1 6 0})$

\begin{tabular}{|c|c|c|c|}
\hline \multirow[t]{2}{*}{ Model } & \multirow[b]{2}{*}{ B } & \multirow[b]{2}{*}{ Beta } & \multirow[b]{2}{*}{ Sig } \\
\hline & & & \\
\hline (Constant) & 3,124 & & $000^{* *}$ \\
\hline Complex sensitive management &,- 130 &,- 096 & ,255 \\
\hline \multicolumn{4}{|l|}{ Characteristics project } \\
\hline - $\quad$ Project phase & ,141 & ,264 &, $002^{* \star}$ \\
\hline - $\quad$ Relationship with other projects & -.070 & -.058 & 478 \\
\hline \multicolumn{4}{|l|}{ Characteristics network } \\
\hline - Size &, 000 &, 000 & ,991 \\
\hline - Interdependencies &,- 097 &,- 095 & ,251 \\
\hline - Differences of opinion & ,020 &, 023 & ,782 \\
\hline \multicolumn{4}{|l|}{ Characteristics respondent } \\
\hline \multicolumn{4}{|l|}{$\begin{array}{l}\text { Position } \\
(\text { manager }=\text { reference category })\end{array}$} \\
\hline participant & 233 & ,125 & ,185 \\
\hline other & ,260 &, 125 & ,177 \\
\hline - Years of experience with complex projects &, 006 & ,061 & ,451 \\
\hline & $\begin{array}{l}\mathrm{R}^{2}=, 110 \\
\mathrm{R}_{\text {adj }}^{2}=, 054\end{array}$ & & \\
\hline
\end{tabular}

$* \mathrm{p}<0.05 * * \mathrm{p}<0.01$ 
There is no significant correlation between complexity sensitive management and procedural legitimacy. Hence, our third hypothesis cannot be confirmed. There is a correlation between project phase and procedural legitimacy. This indicates that in the end of complex water governance processes following and sticking to procedures becomes more important.

\section{Conclusion and discussion}

In this chapter we focused on connective capacity by investigating the complexity sensitive management style regarding the development of legitimacy in complex water governance networks. Complexity sensitive management is especially focused on the compounded and integrated whole of a network and tries to interconnect different parts (actors, arenas, etc.) in this network. Water governance networks are characterized by horizontal relationships between actors, which raise questions concerning the legitimacy of these networks and the relationship with existing institutions of politics and policy making based on the foundations of representative democracy and vertical accountability structures (Koppenjan and Klijn, 2004; Wagenaar, 2007). The literature on governance networks is ambiguous regarding this relationship and is empirically not well developed. Building on the literature on legitimacy we distinguished three forms of legitimacy in this chapter, which we considered to be of importance for studying water governance networks: output legitimacy, throughput legitimacy and procedural legitimacy.

Furthermore, given the complex, erratic and unpredictable nature of governance networks, we argued that a complexity sensitive management style is more effective for realizing output and throughput legitimacy. Such a management style is aimed at creating the context in which effective and legitimate governance processes could evolve (UhlBien et al, 2007; Teisman et al, 2009).

Before drawing conclusions from our research we stress that care must be taken in making generalizations from this research. Firstly, this study has focused on specific kinds of governance networks; all the networks studied were in the field of water resource management. These results cannot automatically be assumed to also hold for other types of public projects or policy domains, such as (social) service delivery networks (Meier and O'Toole, 2001; 2003). Each field, domain or network has its own characteristics and contextual features, which might influence the results found in this study. Secondly, the study was conducted in The Netherlands, and the projects are all Dutch. The results may differ in other countries with different decision-making cultures. Despite these limitations we believe that we provided useful new insights regarding the management and legitimacy in the context of complex governance networks.

Our first conclusion is that complexity sensitive management has a positive impact on the output legitimacy of the water projects. A complexity sensitive management style is focused on actor interdependencies in the water governance networks and has an eye for emerging dynamics occurring in such networks. The manager is focused on exploration and connection of different aspects and viewpoints regarding the complex issue (Uhl- 
Bien et al, 2007; Edelenbos et al, 2009). The inclusion of the diversity of interests and values in solutions leads to relevant and supported outcomes.

Our second conclusion is that complexity sensitive management has a positive impact on throughput legitimacy. The relationship in our survey-research is very strong. A complexity sensitive management style is focused on inclusion of stakeholders, on transparency of the process and on creating opportunities for interaction, deliberation and debate. This leads to higher (perceived) throughput legitimacy in governance networks. The complexity sensitive manager plays an important role in connecting practices in governance networks with deliberative forms of democracy and could in this way enhance the legitimacy of governance networks.

The relationship between procedural legitimacy and complexity sensitive management could not be confirmed. We did found, however, that procedural legitimacy is negatively correlated with output and throughput legitimacy. This indicates that different forms of legitimacy could contradict with each other. Further research is needed under which circumstances this occurs. For example, the level of conflict or trust within governance networks could be such conditioning factors. A low level of trust as starting condition, for example, could imply that actors are more inclined to procedural legitimacy and less to throughput legitimacy because they want security from written agreements and less from process based rule-making (c.f. Das and Teng, 2001).

Overall we can conclude that connective capacity via complexity sensitive managerial strategies is important for bringing societal and governmental spheres in water governance networks together and enhancing the legitimacy of the working and functioning of governance networks in the field of water (resource) management. A complexity sensitive style is therefore an important factor for connective capacity building in complex water governance networks. 


\section{References}

Bekkers, V., and A. Edwards (2007). Legitimacy and Democracy: A Conceptual Framework for Assessing Governance Practices. In: Bekkers, V., G. Dijkstra, A. Edwards and M. Fengers (Eds). Governance and the Democratic Deficit. Assessing the Democratic Legitimacy of Governance Practices. Ashgate, Hampshire.

Berry, J.M., K.E. Portney \& K. Thomson (1993) The Rebirth of Urban Democracy, The Brookings Institution, Washington DC.

Buuren A. van, J. Edelenbos and E.H. Klijn (2010). Gebiedsontwikkeling in woelig water. Over water governance bewegend tussen adaptief waterbeheer en ruimtelijke ontwikkeling. Boom/Lemma, Den Haag

Das, T.K. and Teng B. (2001) 'Trust, control, and risk in strategic alliances: an integrated framework', Organization studies, 22(2): 251-83.

Dryzek, J.S. (2000), Deliberate democracy and beyond; liberals, critics, contestations, Oxford: Oxford University Press

Edelenbos, J. and G. Teisman (2011). Symposium on water governance. Prologue: water governance as a government's actions between the reality of fragmentation and the need for integration. International Review Of Administrative Sciences, 77(1): 5-30.

Edelenbos, J. (2010) Water as connective current, inaugural speech. Den Haag: Boom/Lemma.

Edelenbos, J., B. Steijn and E.H. Klijn (2010). Does Democratic Anchorage Matter?

An Inquiry Into the Relation Between Democratic Anchorage and Outcome of Dutch Environmental Projects. The American Review of Public Administration 2010, 40: 4663.

Edelenbos, J. E.H. Klijn and M. Kort (2009), Managing complex process systems: surviving at the edge of chaos, in: Teisman, G.R., A. van Buuren and L. Gerrits (eds.), Managing Complex Governance Systems, pp 172-192.

Edelenbos, J., \& Klijn, E. H. (2006). Managing stakeholder involvement in decision making: A comparative analysis of six interactive processes in the Netherlands. Journal of Public Administration Research and Theory, 16(3), 417-446.

Esmark, A. (2007). Democratic Accountability and Network Governance. Problems and Potentials. In: E. Sørensen and J. Torfing (ed.). Theories of Democratic Network Governance. London: Palgrave.

Gage, R.W., and M.P. Mandell (eds.) (1990). Strategies for Managing Intergovernmental Policies and Networks. New York: Praeger. 
Grant, R.W. and R.O. Keohane (2005). Accountability and Abuses of Power in World Politics. American Political Science Review, Vol. 99, No. 1, pp. 1-15.

Hanf, K., and F.W. Scharpf (eds.) (1978). Interorganizational Policy Making; Limits to Coordination and Central Control. London: Sage Publications.

Hazy, J.K. (2008). Patterns of Leadership. A case study of influence signaling in an entrepreneurial firm, in: Uhl-Bien, M and R. Marion (eds.), Complexity Leadership, Part 1: Conceptual Foundations, Charlotte: Information Age Publishing, pp. 379-415.

Held, D. (2006), Models of democracy, Cambridge: Polity Press

Hirst, P., (1997), From statism to pluralism; democracy, civil society and global politics, London: UCL Press

Jackson MC (2000). Systems Approaches to Management. Kluwer/Plenum: New York

Kersbergen, K. van, and F. van Waarden (2004). "Governance” as a Bridge Between Disciplines. European Journal of Political Research, 43 (2), 143-71.

Kickert, W. J. M., Klijn, E.-H., \& Koppenjan, J. F. M. (Eds.). (1997). Managing complex networks: Strategies for the public sector. London: Sage.

Klijn, E.H. (2010). Creating (output) legitimacy by interactive decision-making. Paper for the section 'Interactive Governance, Policy Innovation and Democracy', panel Is interactive governance democratic?', 9-11 September 2009, Potsdam, Potsdam University

Klijn, E.H., B. Steijn and J. Edelenbos (2010). The Impact of Network Management on Outcomes in Governance Networks. Public Administration.

Klijn, E.H., and C. Skelcher (2007). Democracy and Governance Networks: Compatible or Not? Public Administration 85 (3): 587-608.

Kooiman, J. (ed.) (1993). Modern governance: New government-society interactions. London: Sage.

Kooiman, J. (2000). Societal governance: levels, models and orders of social-political Interaction. In: J. Pierre (ed.). Debating Governance: Authority, Steering and Democracy. London: Sage.

Koppenjan, J., \& Klijn, E. H. (2004). Managing uncertainties in networks. London: Routledge.

Lubell, M. And L. Lippert (2011). Integrated regional water management: a study of collaboration or water politics-as-usual in California, USA. International Review Of Administrative Sciences, 77(1): 76-100. 
March, J.G. and J.P. Olsen (1995). Democratic Governance. New York: Free Press.

Marsh, D., Rhodes, R.A.W. (eds.), (1992), Policy networks in Britisch Government, Oxford: Clarendon Press

MacPherson, C.B. (1979). The Life and Times of Liberal Democracy, Oxford: Oxford University Press.

Meier, K.J. and L.J. O'Toole (2001) 'Managerial strategies and behaviour in networks: a model with evidence from U.S. public education', in: Journal of Public Administration and Theory (11) 3: 271-293.

Meier, K. L.J. O'Toole (2007). Modelling Public Management: empirical analysis of the management-performance nexus. Public Administration Review, 9(4), 503-527.

Pahl-Wostl, C. (2007). Transitions towards adaptive management of water facing climate and global change. Water Resour Manag 21(1):49.

Pateman, C., (1970), Participation and democratic theory, Cambridge: Cambridge University Press

Pierre, J. (ed.) (2000). Debating Governance; authority steering and democracy, Oxford: Oxford University Press.

Pierre, J. and B. Guy Peters. 2000. Governance, Politics and the State. Basingstoke: Macmillan.

Rhodes, R.A.W. (1997), Understanding Government, Open University Press, Buckingham.

Rogers, D. L., and D. A. Whetten (1982). Interorganizational Coordination: Theory, Research and Implementation. Iowa State University Press, Ames, Iowa.

Rosenhead, J. (1998). Complexity Theory and Management Practice. Science as Culture, http://humannature. com/science-as-culture/rosenhead.html.

Scharpf, F.W. (1999). Governing in Europe: effective and democratic? Oxford University Press, Oxford.

Schreiber, C. \& K.M. Carley (2008). Network Leadership. Leading for Learning and Adaptability, in: Uhl-Bien, M and R. Marion (eds.), Complexity Leadership, Part 1: Conceptual Foundations, Charlotte: Information Age Publishing, pp 291-331

Senge, P. M. (1990). The fifth discipline: The art and practice of organizational learning. New York: Doubleday. 
Skelcher, C. (2007). Does Democracy Matter? A Transatlantic Research Design on Democratic Performance and Special Purpose Governments, Journal of Public Administration Research and Theory, vol.17(1), pp.61-76.

Sørenson E. and J. Torfing (eds.) (2007), Theories of democratic network governance, Cheltenham: Edward Elgar

Teisman, G.R., M.W. van Buuren and L.G. Gerrits (2009) Managing Complex Governance Systems. London: Routledge.

Uhl-Bien, M., R. Marion and B. McKelvey (2007). Complexity Leadership Theory: Shifting leadership from the industrial to the knowledge era. The Leadership Quaterly, 18: 298-318.

Wagenaar, H. (2007). Governance, Complexity, and Democratic Participation: How Citizens and Public Officials Harness the Complexities of Neighbourhood Decline. American Review of Public Administration, 37(1): 17-50.

Young, I.M., (2000). Inclusion and Democracy. Oxford University Press, Oxford.

Young, I.M., (2001). 'Activist Challenges to Deliberative Democracy'. Political Theory, 29(5): 670-90. 


\section{Appendix I: The items of the core variables}

\section{Measurement of the independent variable: complexity sensitive management}

\begin{tabular}{|c|c|}
\hline Dimension & Item \\
\hline $\begin{array}{l}\text { 1. Complexity of the project: } \\
\text { connecting multiple spatial } \\
\text { functions }\end{array}$ & $\begin{array}{l}\text { 1. The manager is aimed at connecting different } \\
\text { spatial functions in the development of the project }\end{array}$ \\
\hline $\begin{array}{l}\text { 2. Complexity of the actor } \\
\text { environment (a): adapting the } \\
\text { project to the environment }\end{array}$ & $\begin{array}{l}\text { 2. The manager is aimed at adapting the project to } \\
\text { the demands and wishes of the stakeholders }\end{array}$ \\
\hline $\begin{array}{l}\text { 3. Complexity of the actor } \\
\text { environment (b): keeping the } \\
\text { project in line with stakeholders' } \\
\text { expectations }\end{array}$ & $\begin{array}{l}\text { 3. The manager creates enough moments for the } \\
\text { representatives of the different involved parties for } \\
\text { feedback to their grassroots }\end{array}$ \\
\hline $\begin{array}{l}\text { 4. Complexity of the actor } \\
\text { environment (c): connecting } \\
\text { different interests }\end{array}$ & $\begin{array}{l}\text { 4. The manager is aimed at connecting different } \\
\text { parties with different interests as much as possible }\end{array}$ \\
\hline
\end{tabular}

The mean score on complexity sensitive management is $3,74(\mathrm{SD}=0,67)$ on a five point Likert scale. The Cronbach's alpha of the four items was 0.70 .

\section{Measurement of the dependent variables: legitimacy}

\section{Measurements of output legitimacy}

\section{Dimension}

1.a Problem solving capacity: effectiveness solutions

1.b. Problem solving capacity: robustness of the results 2.a Acceptance of policy outputs: support for the results

2.b. Acceptance of policy outputs: support for the decisions

\section{Items}

Do you think that the solutions that have been developed really deal with the problems at hand?

Do you think that the developed solutions are durable solutions for the future?

Do you think that - in general - the results of the governance process are supported by the involved parties?

Do you think that the substantiation of the decisions are - in general - supported by the involved parties?

\section{Measurements of throughput legitimacy}

\section{Dimension}

1.a Voice: Width participation 1.b.Voice: Access project for participation

\section{Items}

There are a lot different stakeholders involved in the project

The process is good accessible for all stakeholders 
2.a. Transparency:

Organization of information

2.b. Transparency of decision making process

3.a. Due deliberation: Opportunities for debate 3.b. Due deliberation: Quality of argumentation
The information services concerning this project are well organized.

The decision-making process concerning this project is characterized by a high transparency (insight in concrete decisions)

During the process there are a lot of possibilities for debates and discussions

The argumentation concerning this project is careful

Measurements of procedural legitimacy

\section{Dimension}

1. Determination of the process by procedures and rules

1.The emphasizes on procedural rules

\section{Items}

The interaction process is largely determined by formal and a priori legal procedures and rules

In the project there is an emphasizes on the compliance with formal rules and procedures 